\title{
The Development of Systems Engineering International Standards and Support Tools for Very Small Enterprises
}

\author{
Claude Y. Laporte \\ École de technologie supérieure \\ Gauthier Fanmuy \\ ADN \\ Department of Software and IT \\ Engineering \\ 1100, Notre-Dame Street West, Montréal, \\ Québec, Canada, H3C 1K3 \\ Claude.Y.Laporte@etsmtl.ca \\ Phone : +1 5143968956 \\ Ken Ptack \\ INCOSE CSEP \\ Consultant \\ PO Box 285 \\ Bryantown, MD 20617, USA \\ ptack@incose.org \\ Technical Director / System Engineering \\ Skill Center Manager \\ 17 rue Louise Michel \\ 92300 Levallois Perret - France \\ gauthier.Fanmuy@adn.fr \\ Phone: +33 172032392 \\ Mobile : + 33610762906
}

Copyright (C 2012 by C. Y. Laporte, G. Fanmuy, K. Ptack. Permission granted to INCOSE to publish and use.

\begin{abstract}
Industry recognizes that there are very small organizations that develop parts which contain software components. These organizations, those with up to 25 people, are very important to the world-wide economy, and the parts they develop are often integrated into products made by larger enterprises. Failure to deliver a quality product on time and within budget threatens the competitiveness of both organizations. One way to mitigate these risks is for all the suppliers in a product chain put in place proven engineering practices. Many international standards have been developed to capture such proven engineering practices. However, these standards were not written for very small development organizations and are consequently difficult to apply in such settings. An ISO Working Group has been established to address these difficulties. The working group developed standards and technical reports, ISO/IEC 29110, which were published in 2011 for organizations developing software. In 2009 an INCOSE working group was established to evaluate the possibility of developing a standard, using the ISO/IEC 29110 standard as a baseline and the ISO/IEC 15288 as the framework, for organizations developing systems. At the 2011 INCOSE International Workshop, a group of systems engineers reviewed the ISO/IEC 29110 software standard and proposed modifications to meet their needs. One constraint was to develop a document which will allow an organization developing systems with software components to be able to use the actual set of ISO/IEC 29110 standards as well as the proposed systems engineering standards. The future systems engineering standard is targeted at VSEs which do not have experience or expertise in tailoring ISO/IEC 15288. A draft document has been developed and reviewed. Recently, an ISO working group has been mandated to develop the ISO standard for very small organizations developing systems. The INCOSE Systems Engineering Handbook is used as the main reference for the development of a set of systems engineering deployment packages. A deployment package is a set of artefacts developed to facilitate the implementation of a set of practices of a standard in a very small organization.
\end{abstract}




\section{Introduction}

Today, the ability of organizations to compete, adapt, and survive depends increasingly on software. In 2010 a cellular phone contained 20 million lines of code and some cars had up to 100 million lines of code (Charette 2005). Manufacturers depend increasingly on the components produced by their suppliers. A manufacturing chain of large mass-market products often has a pyramidal structure, as illustrated in Figure 1. For example, a large mass product manufacturer recently integrated into one of its products a part with an unknown software error that was produced by one of its 6,000 lower-level producers. This defective part resulted in a loss of over $\$ 200$ million by the mass product manufacturer.

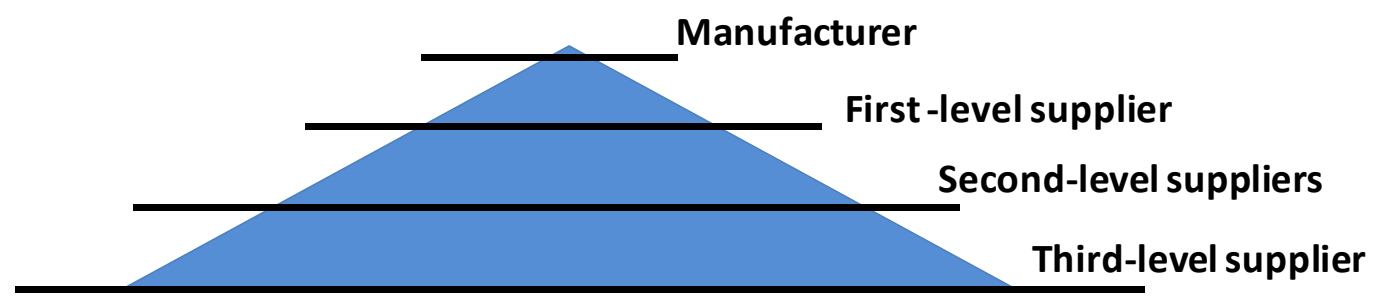

Figure 1 Example of the supply chain of a large manufacturer

(adapted from Shintani 2006)

Industry recognizes the value of VSEs (Very Small Entities), i.e. an entity (enterprise, organization, department or project) having up to 25 people, in contributing valuable products and services. In Europe, for instance, 85\% of the Information Technology (IT) sector's companies have 1 to 10 employees. In Canada, a recent survey of the Montreal area revealed, as illustrated in Table 1, that $78 \%$ of software development enterprises have fewer than 25 employees and 50\% have fewer than 10 employees (Laporte 2005). In Brazil, small IT companies represent about 70\% of the total number of companies (Anaclecto 2004).

\begin{tabular}{|c||c|c|c|c|}
\hline \multirow{2}{*}{\begin{tabular}{c}
\multirow{2}{*}{$\begin{array}{c}\text { Size } \\
\text { (number of } \\
\text { employees) }\end{array}$} \\
\cline { 2 - 5 }
\end{tabular}} & \multicolumn{2}{c|}{$\begin{array}{c}\text { Software } \\
\text { Enterprises }\end{array}$} & \multicolumn{2}{c|}{ Jobs } \\
\cline { 2 - 5 } & Number & $\%$ & Number & $\%$ \\
\hline 1 to 25 & 540 & $78 \%$ & 5,105 & $29 \%$ \\
\hline 26 to 100 & 127 & $18 \%$ & 6,221 & $36 \%$ \\
\hline over 100 & 26 & $4 \%$ & 6,056 & $35 \%$ \\
\hline \hline TOTAL & $\mathbf{6 9 3}$ & $\mathbf{1 0 0 \%}$ & $\mathbf{1 7 , 3 8 2}$ & $\mathbf{1 0 0 \%}$ \\
\hline
\end{tabular}

Table 1. Size of software development organizations in the Montréal area (translated from Gauthier 2004)

There is a need to help these VSEs understand the benefit of the concepts, processes, and practices described in international engineering standards, and initiate their use.

This paper describes a new project formed to facilitate access to, and utilization of, ISO/IEC JTC1/SC7 systems and software engineering standards by VSEs with up to 25 people. This paper is divided into 5 sections. The remaining sections include: 
- a brief history of the events that led to the establishment of an ISO Working Group, WG24, dedicated to Very Small Entities (VSEs);

- a description of the results of a world-wide survey of VSEs conducted by WG24;

- a description of the approach and processes used by WG24 to produce a set of standards and technical reports for VSEs;

- a description of the proposed systems engineering standard for VSEs developing systems,

- the direction of future work of WG24.

\section{Brief history leading to an ISO Working Group for VSEs developing software}

At the 2004 SC7 Plenary meeting in Australia, Canada raised the issue of small enterprises requiring standards adapted to their size and maturity level. At that time, most software engineering standards were developed by large organizations and targeted (or were perceived as targeting) large organizations. A meeting of interested parties was organized and a consensus was reached on general objectives for a future working group WG. In 2005, a resolution was approved to distribute for ballot the New Work Item (NWI) Proposal for the development of Software Life Cycle Profiles and Guidelines for Use in VSEs. Twelve countries voted in favour of the NWI Proposal (ISO 2005). As a result of this vote, the project was approved and the new working group, WG24, was established. The mandate of WG24 was, using as the main reference ISO/IEC/IEEE 12207 standard (ISO 2008b), the standardization of processes, supporting tools, and supporting technologies for the engineering of software products and systems. A detailed description of its history is available in (Laporte 2006, Laporte 2008).

\section{The Survey of VSEs developing software}

A survey was developed by WG24 to question VSEs developing software about their use of ISO/SC7 standards, as well as to collect data to identify problems and potential solutions to help them apply the standards. The intent was to help VSEs become more accurate and comprehensive in developing their products. From the very beginning, the working group drew up several working hypotheses regarding VSEs. This survey was intended to determine which of these hypotheses were applicable, for example:

- The VSE context requires light and well-focused life cycle profiles.

- Particular business contexts require particular profiles.

- There are significant differences, in terms of available resources and infrastructure, between a VSE employing 1 to 10 people and an Information Technology (IT) department of the same size in a larger company.

- VSEs are limited in terms of both time and resources, which leads to a lack of understanding of how to use the standards for their benefit.

- Benefits for VSEs may include recognition through assessment or audit by an accredited body.

The survey questionnaire and an introductory text were developed by WG24 and translated into 9 languages: English, French, German, Korean, Portuguese, Thai, Turkish, Russian, and Spanish. The survey is made up of 20 questions structured in 5 parts: General information; Information about standards utilization in VSEs; Information about implementation and assessment problems 
in VSEs; Information about VSE needs; and Information about justification for compliance to standard(s).

The most obvious feature of the respondent sample, as illustrated in Table 2, is the geographical distribution of the respondents. We collected from 31 countries a high number of responses from Latin America (46\%), mainly from Colombia and Brazil.

\begin{tabular}{|l|c|l|c|}
\hline \multicolumn{1}{|c|}{ Country } & $\begin{array}{c}\text { Number } \\
\text { of } \\
\text { Responses }\end{array}$ & \multicolumn{1}{|c|}{ Country } & $\begin{array}{c}\text { Number } \\
\text { of } \\
\text { Responses }\end{array}$ \\
\hline Argentina & 2 & Italy & 2 \\
\hline Australia & 10 & Japan & 3 \\
\hline Belgium & 10 & South Korea & 4 \\
\hline Brazil & 70 & Luxembourg & 2 \\
\hline Bulgaria & 3 & Mexico & 20 \\
\hline Canada & 9 & New Zealand & 1 \\
\hline Chile & 1 & Peru & 4 \\
\hline Colombia & 109 & Russia & 4 \\
\hline Czech Republic & 3 & South Africa & 10 \\
\hline Dominican Republic & 1 & Spain & 3 \\
\hline Ecuador & 9 & Taiwan & 1 \\
\hline Finland & 13 & Thailand & 58 \\
\hline France & 4 & Turkey & 1 \\
\hline Germany & 1 & United Kingdom & 2 \\
\hline India & 57 & United States & 3 \\
\hline Ireland & 10 & \multicolumn{2}{|l}{} \\
\hline
\end{tabular}

Table 2. Number of survey responses per country (Laporte 2009)

\section{Use of Standards}

An interesting finding of the survey is the difference in the percentage of certified companies with regard to company size: less than $18 \%$ of the VSEs are certified, while $53 \%$ of larger companies (more than 25 employees) claim to be certified. Furthermore, among the 18\% not certified, $75 \%$ do not use standards.

WG24 anticipated the weak use of standards by VSEs by asking questions designed to provide a better understanding of the reasons for this. There are three main ones, as shown in Figure 2. The first is a lack of resources (28\%); the second is that standards are not required (24\%); and the third derives from the nature of the standards themselves: $15 \%$ of the respondents consider that the standards are difficult and bureaucratic, and do not provide adequate guidance for use in a small business environment. 


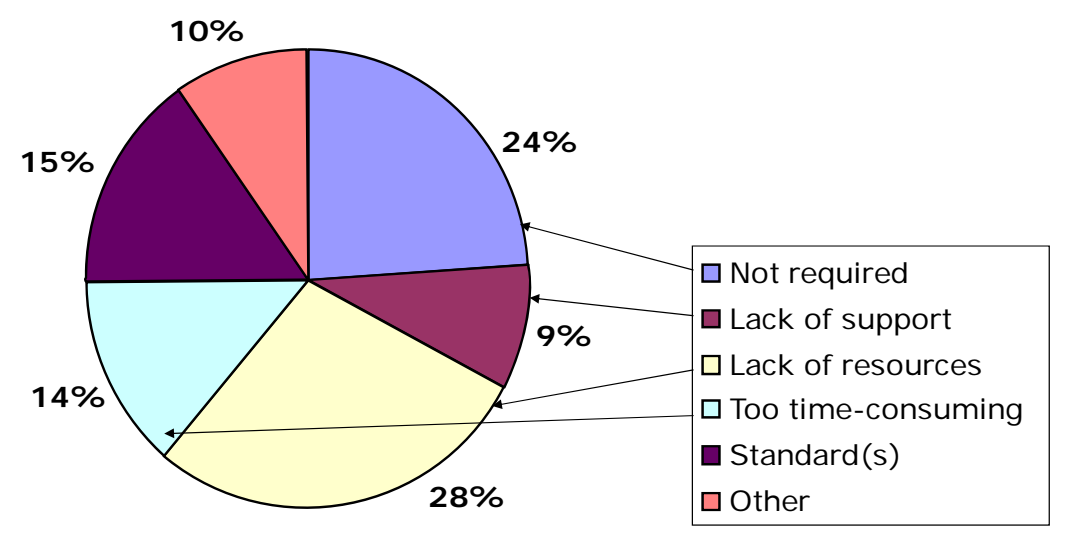

Figure 2. Why don't VSEs use standards? (Laporte 2008)

For a large majority (74\%) of VSEs, it is very important to be evaluated or certified against a standard. ISO certification is requested by $40 \%$ of them. Of the $28 \%$ requesting official market recognition, only $4 \%$ are interested in a national certification. From the VSE perspective, some benefits provided by certification are:

- increased competitiveness,

- greater customer confidence and satisfaction,

- greater software product quality,

- increased sponsorship for process improvement,

- decreased development risk,

- facilitation of marketing (e.g. a better image),

- higher potential for export.

However, VSEs are expressing the need for assistance in adopting and implementing standards. Over $62 \%$ would like more guidance with examples, and 55\% are asking for lightweight and easy-to-understand standards, complete with templates. Finally, the respondents have indicated that it has to be possible to implement standards with minimum cost, time, and resources. All data about VSEs and standards clearly confirm WG24's hypothesis and the requirements. Therefore, WG24 is using this information for the development of profiles, guides, and templates to meet VSE needs.

\section{The WG 24 approach to the development of International Standards for VSEs developing software}

The approach used by WG24 had to take into account, as a starting point, the ISO requirements in terms of the definition of a standard. Indeed, since an international standard dedicated to the system life cycle was already available (i.e. ISO 12207) (ISO 2008a), WG24 used the concept of ISO profiles (Standardized Profile, SP) to develop the new software (SW) standard for VSEs. Formally, a profile is defined as "A set of one or more base standards and/or SPs, and, where applicable, the identification of chosen classes, conforming subsets, options and parameters of those base standards, or SPs necessary to accomplish a particular function” (ISO 1998). From a practical point of view, a profile is a kind of matrix which identifies precisely all elements that are taken from existing standards from those that are not. This prevents the new standard from 
copying the content of existing standards, but allows to the highlighting of some clauses if and when appropriate.

The overall approach followed by WG24 to develop this new standard for VSE consisted of three steps:

- Develop a set of profiles for VSEs not involved in critical software development

- Select the ISO 122207 process subset applicable to VSEs with up to 25 people,

- Tailor the subset to fit VSE needs,

- Develop guidelines, checklists, templates, examples.

\section{Profiles}

The core characteristic of the entities targeted by ISO/IEC 29110 is size, however there are other aspects and characteristics of VSEs that may affect profile preparation or selection, such as: Business Models (commercial, contracting, in-house development, etc.); Situational factors (such as criticality, uncertainty environment, etc.); and Risk Levels. Creating one profile for each possible combination of values of the various dimensions introduced above would result in an unmanageable set of profiles. Accordingly, VSE profiles are grouped in such a way as to be applicable to more than one category. Profile Groups are a collection of profiles which are related either by composition of processes (i.e. activities, tasks), or by capability level, or both.

\section{Generic Profile Group}

The Generic Profile Group has been defined as applicable to a vast majority of VSEs that do not develop critical software and have typical situational factors (ISO 2011b). The Generic Profile Group is a collection of four profiles (Entry, Basic, Intermediate, Advanced), providing a progressive approach to satisfying a vast majority of VSEs. VSEs targeted by the Entry Profile are VSEs working on small projects (e.g. at most six person-months effort) and for start-up VSEs. The Basic Profile describes software development practices of a single application by a single project team with no special risk or situational factors. The Intermediate Profile is targeted at VSEs developing multiple projects within the organizational context taking advantage of it. The Advanced Profile is target to VSEs which want to sustain and grow as an independent competitive software development business. The ISO/IEC 29110 series were not intended to dictate the use of different life cycles such as: waterfall, iterative, incremental, evolutionary or agile.

The set ISO/IEC 29110 documents are (ISO 2011a):

- ISO/IEC TR 29110-1 (Overview) defines the business terms common to the VSE Profile Set of Documents. It introduces processes, lifecycle and standardization concepts, and the ISO/IEC 29110 series. It also introduces the characteristics and requirements of a VSE, and clarifies the rationale for VSE-specific profiles, documents, standards and guides (ISO 2011a).

- ISO/IEC 29110-2 (Framework and taxonomy) introduces the concepts for software engineering standardized profiles for VSEs, and defines the terms common to the VSE Profile Set of Documents. It establishes the logic behind the definition and application of standardized profiles. It specifies the elements common to all standardized profiles (structure, conformance, assessment) and introduces the taxonomy (catalogue) of ISO/IEC 29110 profiles (ISO 2011b). 
- ISO/IEC TR 29110-3 (Assessment Guide) defines the process assessment guidelines and compliance requirements needed to meet the purpose of the defined VSE Profiles. ISO/IEC TR 29110-3 also contains information that can be useful to developers of assessment methods and assessment tools. ISO/IEC TR 29110-3 is addressed to people who have direct relation with the assessment process, e.g. the assessor and the sponsor of the assessment, who need guidance on ensuring that the requirements for performing an assessment have been met (ISO 2011c).

- ISO/IEC 29110-4-1 (Profile specifications) provides the specification for all the profiles of the Generic Profile Group. The Generic Profile Group is applicable to VSEs that do not develop critical software products. The profiles are based on subsets of appropriate standards elements. VSE Profiles apply and are targeted at authors/providers of guides and authors/providers of tools and other support material (ISO 2011d).

- ISO/IEC TR 29110-5-m-n (Management and engineering guide) provides an implementation management and engineering guide for the VSE Profile described in ISO/IEC 29110-4-m (ISO 2011e).

The ISO/IEC 29110 documents are targeted by audience as described in Table 3.

\begin{tabular}{|l|l|l|}
\hline $\begin{array}{l}\text { ISO/IEC } \\
\mathbf{2 9 1 1 0}\end{array}$ & Title & Target audience \\
\hline Part 1 & Overview & $\begin{array}{l}\text { VSEs, assessors, standards producers, } \\
\text { tool vendors, and methodology vendors. }\end{array}$ \\
\hline Part 2 & Framework and taxonomy & $\begin{array}{l}\text { Standards producers, tool vendors and } \\
\text { methodology vendors. Not intended for } \\
\text { VSEs. }\end{array}$ \\
\hline Part 3 & Assessment guide & Assessors and VSEs \\
\hline Part 4 & Profile specifications & $\begin{array}{l}\text { Standards producers, tool vendors and } \\
\text { methodology vendors. Not intended for } \\
\text { VSEs. }\end{array}$ \\
\hline Part 5 & Management and engineering guide & VSEs \\
\hline
\end{tabular}

Table 3. ISO/IEC 29110 target audience (ISO 2011e)

The SW Basic Profile Standards ISO/IEC 29110-2 and ISO/IEC 29110-4-1 have been published by ISO in January 2011, the Engineering and Management Guide, ISO/IEC 29110-5-1-2, was published in May 2011, the Overview Guide, ISO/IEC 29110-1 and the Assessment Guide, ISO/IEC 29110-3, were published in September 2011.

At the request of WG24, the 3 technical reports (i.e. the guides) are available at no cost from ISO (http://standards.iso.org/ittf/PubliclyAvailableStandards/index.html). Part 1 and Part 5 are translated in French and Spanish and the set of 5 documents have been translated in Portuguese by the Riosoft organization of Brazil (www.riosoft.softex.br). Japan has also started the translation of ISO/IEC 29110. 


\section{History leading to the approval of an ISO project to develop standards and guides for VSEs developing systems}

A paper about the development of standards for VSEs developing software had been presented at the 2008 INCOSE conference (Laporte 2008). This presentation triggered the idea, of members of the INCOSE Board of Directors, of setting up a working group to develop a set of standards and guides, for systems engineering VSEs, similar to the one developed for software VSEs.

A new working group was mandated in 2009, by INCOSE, to apply systems engineering to product development for small and very small entities. The working group, created in April 2009, co-chaired by the authors, is composed of INCOSE and AFIS members from Canada, France, Germany, and the US.

At the first meeting of the INCOSE working group, one of the co-authors proposed an approach similar to that developed by WG24, i.e. the conducting of a survey, the development of a set of requirements, the creation of profiles and deployment packages, and the conduct of pilot projects. The members of the working group agreed with this proposition. The initial goals of the working group were to (INCOSE 2009):

- Improve or make product development efficient by using systems engineering methodology,

- Elaborate tailored practical guidance to apply to very small and medium-sized enterprises (VSMEs) in the context of the prime contractor or subcontractor of commercial products,

- Contribute to standardization

The initial set of deliverables was the following:

- Roadmaps and deployment packages (process, check list, templates, training support, coverage matrices with standards),

- Lessons learned from pilot projects,

- Case studies,

- Mapping of tailored activities with the INCOSE Systems Engineering (SE) Handbook and ISO Standards (e.g. ISO 15288), as well as other recommended frameworks (e.g. CMMI ${ }^{\circledR}$ models developed by the Software Engineering Institute (SEI 2010)),

- Supplements to the INCOSE Systems Engineering Handbook (INCOSE 2010),

- Technical communication with INCOSE membership through papers, presentations, and Webinars

\section{The development of the Basic Profile for VSEs developing systems}

The purpose of the Basic Systems Engineering (SE) Profile is to define a subset of processes and outcomes of ISO/IEC/IEEE 15288 (ISO 2008b) and products of ISO/IEC 15289 (ISO 2011h) for system development and project management for a VSE developing one project at a time. The Basic SE Profile will be designed to match the existing Basic Software Engineering profile of ISO/IEC 29110. The preparation of the Basic Systems Engineering profile followed these steps:

a) At the first meeting of the INCOSE/AFIS working group, it was proposed that an approach similar to that developed by WG24, i.e. the conducting of a survey, the development of a set of requirements, the creation of profiles and deployment packages, 
and the conducting of pilot projects be used. The members of the working group agreed with this proposition.

b) A survey was developed, translated in 5 languages and conducted. Unfortunately not many people responded to the survey.

c) The working group decided to use ISO 15288 as the main reference for the SE standard and to use the INCOSE Handbook for the development of Deployment Packages to support the standards and guides.

d) End 2010, a first draft of SE engineering and management guide was developed on the basis of the ISO 29110 basic profile. References to ISO 15288 were added. Applicable software tasks/deliverables on systems were kept (e.g. project management tasks), irrelevant software tasks/deliverables were excluded (e.g. detailed architecture). Specific system tasks/deliverables were added (e.g. Functional and physical architecture). New artifacts and participants were added (e.g. Stakeholder, System Engineer)

e) At the 2011 International Workshop of INCOSE, held in Phoenix, the first draft of SE Basic profile engineering and management guide was reviewed by a group of systems engineers. They decided that this document could be easily used as a baseline to develop a similar profile in a future ISO standard, i.e. a Basic profile, for systems engineering. The participants discussed the project management and system implementation processes and decided to add few tasks and artifacts.

f) The document produced at the workshop was then distributed for review by INCOSE and AFIS systems engineers.

g) The comments were discussed and a new version of the document was produced,

h) It was decided to table this document at the 2011 SC7 plenary meeting in order to seek support for the formal development of an International standard.

i) A proposal to develop a new set of SE standards for VSEs was prepared, by one of the co-author, and tabled by Canada at the France meeting in May 2011 (ISO 2011f),

j) The following resolution was unanimously approved at the 2011 SC7 plenary session in Paris (ISO 2011g):

- The scope of this work includes the current scope of ISO/IEC 15288, the associated guidance documents and other relevant SC7 Standards such as ISO/IEC 15289 and ISO/IEC 29110. The project will produce Standards and Technical Reports (Guides), similar to the ISO/IEC 29110 set of SW documents for the Generic profile group (i.e. for VSEs developing non critical system), which establishes a common framework for describing assessable system engineering life cycle profiles for Very Small Entities (VSEs).

- If and when the New Project is approved, JTC 1/SC 7 instructs its Secretariat to:

- Assign the project to Working Group 24

- Appoint as project editor: Mr. Claude Y. Laporte, subject to approval of the Canadian national body

- The project will be coordinated with the IEEE Computer Society under the terms of the PSDO. It and INCOSE will participate as Category A Liaisons.

- This project will use the default timeframe, and start on Nov 7, 2011.

k) In August 2011, the proposal as well as a draft SE Engineering and management guide for the Basic profile were circulated for approval to the members of SC7, 
l) In September 2011, the proposal to develop SE standards for VSEs has been accepted by twenty countries. Nine countries made a commitment to participate in the development of the new ISO Systems Engineering standard.

m) In November 2011, the new delegates of WG24 met in Dublin (Ireland) to launch the official development of the SE standards and guides for VSEs. Delegates from Canada, Brazil, France, Japan, Thailand and INCOSE participated to the first meeting.

\section{Description of the draft Engineering and Management Guide of the Systems Engineering Basic profile}

In this section we provide a description of the draft project management and systems engineering processes of the future Engineering and Management guide (i.e. Part 5).

\section{Overview of the project management and system implementation processes}

The purpose of the Project Management (PM) process is to establish and carry out in a systematic way the tasks of the System Implementation (SY) process, which allows complying with the project's objectives in the expected quality, time and cost. The purpose of the SY process is the systematic performance of the analysis, design, construction, Integration Verification -Validation and Qualification (IVVQ) activities for new or modified system according to the specified requirements. Both processes are interrelated as illustrated in Figure 3.

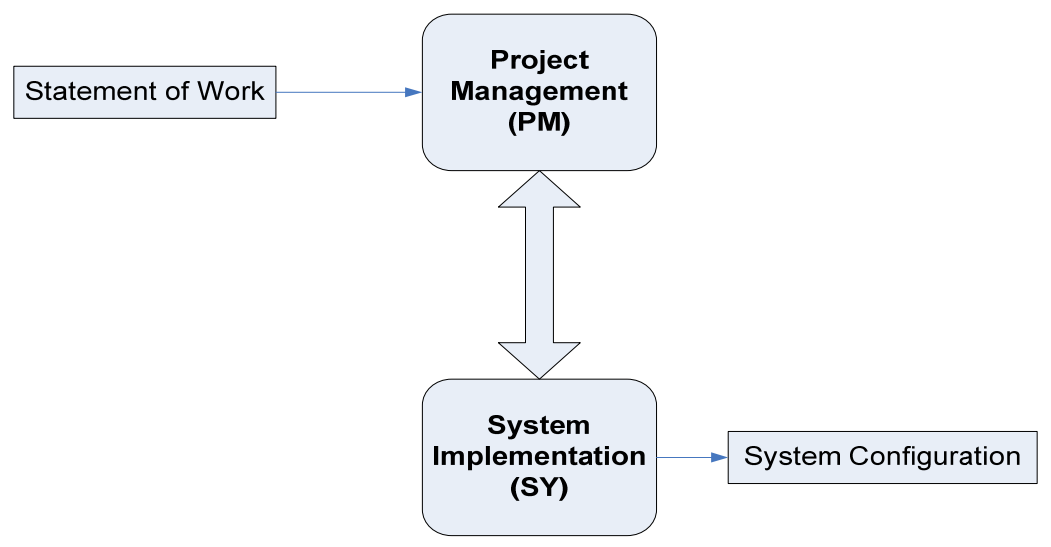

Figure 3. Processes of the systems engineering proposed SE Basic Profile (ISO 2012)

It is to be noted that the proposed SE standard is not intended to dictate the use of different lifecycles such as: waterfall, iterative, incremental, evolutionary or agile.

\section{Project Management Process}

The purpose of the PM process is to establish and carry out in a systematic way the tasks of the system development project, which allows complying with the project's objectives in the expected quality, time and costs.

\section{PM Process Objectives}

The seven objectives of the PM process are (ISO 2012): 
1. PM.O1. The Project Plan for the execution of the project is developed according to the Statement of Work and reviewed and accepted by the Acquirer. The Tasks and Resources necessary to complete the work are sized and estimated.

2. PM.O2. Progress of the project is monitored against the Project Plan and recorded in the Progress Status Record. Corrections to remediate problems and deviations from the plan are taken when project targets are not achieved. Closure of the project is performed to get the Acquirer acceptance documented in the Acceptance Record.

3. PM.O3. The Change Requests are addressed through their reception and analysis. Changes to system requirements are evaluated by the project team for cost, schedule, risks and technical impact.

4. PM.O4. Review meetings with the Work Team and the Acquirer, suppliers are held. Agreements are registered and tracked.

5. PM.O5. Risks are identified as they develop and during the conduct of the project.

6. PM.O6. A System Configuration Management Strategy is developed. Items of System Configuration are identified, defined and baselined. Modifications and releases of the items are controlled and made available to the Acquirer and Work Team. The storage, handling and delivery of the items are controlled.

7. PM.O7. Quality Assurance is performed to provide assurance that work products and processes comply with the Project Plan and System Requirements Specifications.

To show the links between ISO 15288 and the objectives of the PM process we illustrate in figure 4 the outcomes of the project planning process and the measurement process used as objective 1 of the PM Process.

\subsubsection{Project Planning Process}

a) Project plans are available;

e) Plans for the execution of the project are activated.

\subsubsection{Measurement Process}

a) The information needs of technical and management processes are identified [ISO/IEC 15288, 6.3.1, 6.3.7]

Figure 4. Links between the ISO15288 outcomes and objective 1 of the PM process (ISO 2012)

\section{Modifications to the PM process of the ISO 29110 SW engineering Basic Profile}

Very few modifications were made to the SW engineering Basic profile when developing the PM process of the SE Basic profile. To tasks PM1.2 and PM 2.4, the role of Customer was replaced by the role of an Acquirer and Stakeholders. Two new tasks were added: PM1.3, to define the system breakdown structure and PM. 1.11 to identify and document a disposal management approach. Identify and document risks in PM.1.10 was replaced by Identify and document a Risk Management Approach. The Version Control Strategy was replaced by Configuration Management Strategy in PM.1.12. Task PM.4.3 was added to the project closure Activity: Execute the Disposal Management Approach. Table 4 illustrates the format of the new and modified tasks described in the SE management and engineering guide. 


\begin{tabular}{|c|c|c|c|}
\hline Role & $\begin{array}{c}\text { Task List } \\
\end{array}$ & Input Products & Output Products \\
\hline $\begin{array}{l}\text { PM } \\
\text { ACQ }\end{array}$ & $\begin{array}{l}\text { PM.1.2 Define with the Acquirer the Delivery } \\
\text { Instructions of each one of the Deliverables } \\
\text { specified in the Statement of Work. }\end{array}$ & $\begin{array}{l}\text { Statement of Work } \\
\text { [reviewed] }\end{array}$ & $\begin{array}{l}\text { Project Plan } \\
\text { - Delivery } \\
\text { Instructions }\end{array}$ \\
\hline $\begin{array}{l}\text { PM } \\
\text { DES }\end{array}$ & $\begin{array}{l}\text { PM.1.3 Define the System Breakdown Structure } \\
\text { that represents the relationship between the system } \\
\text { and its sub-systems and system elements }\end{array}$ & System Design & $\begin{array}{l}\text { System Breakdown } \\
\text { Structure }\end{array}$ \\
\hline $\begin{array}{l}\text { PM } \\
\text { TL }\end{array}$ & $\begin{array}{l}\text { PM.1.10 Identify and document a Risk } \\
\text { Management Approach and the risks which may } \\
\text { affect the project. }\end{array}$ & $\begin{array}{l}\text { All elements previously } \\
\text { defined }\end{array}$ & $\begin{array}{l}\text { Project Plan } \\
\\
\text { - Risk Management } \\
\text { Approach } \\
\text { - Identification of } \\
\quad \text { Project Risks }\end{array}$ \\
\hline $\begin{array}{l}\mathrm{PM} \\
\mathrm{TL}\end{array}$ & $\begin{array}{l}\text { PM. } 1.11 \text { identify and document the strategy a } \\
\text { disposal management approach }\end{array}$ & & $\begin{array}{l}\text { Project Plan } \\
\text { Disposal Management } \\
\text { Approach }\end{array}$ \\
\hline PM & $\begin{array}{l}\text { PM.1.12 Document the Configuration } \\
\text { Management Strategy in the Project Plan. }\end{array}$ & & Project Plan \\
\hline $\begin{array}{l}\text { PM } \\
\text { ACQ } \\
\text { STK } \\
\text { TL } \\
\text { WT }\end{array}$ & $\begin{array}{l}\text { PM.2.4 Conduct revision meetings with the } \\
\text { Acquirer, Stakeholders, record agreements and } \\
\text { track them to closure. } \\
\text { Change Request initiated by Acquirer, } \\
\text { Stakeholders, or initiated by Work Team, which } \\
\text { affects the Acquirer, Stakeholders needs to be } \\
\text { negotiated to reach acceptance of both parties. } \\
\text { If necessary, update the Project Plan according to } \\
\text { new agreement with Acquirer and other } \\
\text { stakeholders. }\end{array}$ & $\begin{array}{l}\text { Project Plan } \\
\text { Progress Status Record } \\
\text { Change Request } \\
\text { [evaluated] }\end{array}$ & $\begin{array}{l}\begin{array}{l}\text { Meeting Record } \\
\text { [updated] }\end{array} \\
\text { Change Request } \\
\text { [accepted] } \\
\text { Project Plan [updated] }\end{array}$ \\
\hline PM & $\begin{array}{l}\text { PM.4.3 Execute the Disposal Management } \\
\text { Approach }\end{array}$ & Project Plan & Disposed System \\
\hline
\end{tabular}

Table 4 Project Management tasks added of modified (ISO 2012)

Figure 5 shows the flow of information between the Project Management Process activities including the most relevant work products and their relationships. 


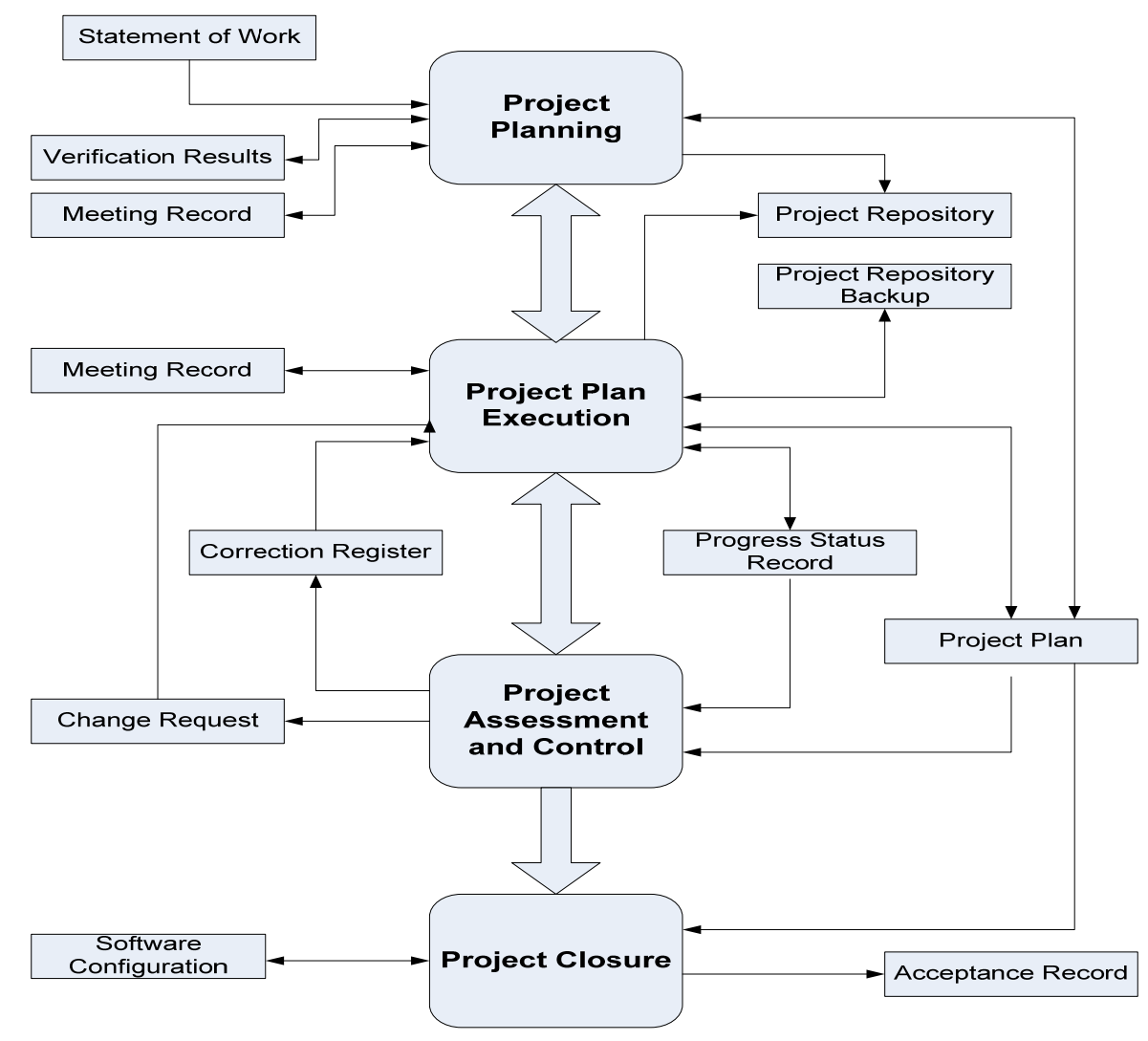

Figure 5. Project Management process diagram of the proposed SE Basic Profile (ISO 2012)

\section{System Implementation Process}

The purpose of the System Implementation (SY) process is the systematic performance of the specification of system/sub-systems, analysis, design, construction, integration and verification/validation activities for new or modified system according to the specified requirements.

\section{SY Process Objectives}

The seven objectives of the SY process are (ISO 2012):

1. SY.O1. Tasks of the activities are performed through the accomplishment of the current Project Plan.

2. SY.O2. System requirements are defined, analyzed for correctness and testability, approved by the Acquirer, baselined and communicated.

3. SY.O3. The System architectural design is developed and baselined. It describes the System elements and internal and external interfaces of them. Consistency and traceability to system requirements are established.

4. SY.O4. System elements defined by the design are produced or acquired. Acceptance tests are defined and performed to verify the consistency with requirements and the design. Traceability to the requirements and design are established.

5. SY.O5. System elements are integrated. Defects encountered during integration are corrected and consistency and traceability to System Design are established. 
6. SY.O6. A System configuration, that meets the Requirements Specification as agreed to with the Acquirer and other stakeholders, which includes user, operation and maintenance documentations is integrated, baselined and stored at the Project Repository. Needs for changes to the System Configuration are detected and related change requests are initiated.

7. SY.O7. Verification and Validation Tasks of all required work products are performed using the defined criteria to achieve consistency among output and input products in each activity. Defects are identified, and corrected; records are stored in the Verification/Validation Results.

\section{Modifications to the Software Implementation process of the ISO 29110 SW Basic Profile} Some significant changes were made to the software implementation (SI) process of the ISO 29110 basic profile: new system activities and tasks were added, irrelevant SW activities were suppressed, new system roles were defined. Also, new system documents were added as the result of the addition/modification to the tasks. We describe below the additions and modifications made to the SW Basic profile in order to develop a first version of the System Implementation (SY) process.

\section{Modifications to Activity SI.2 - Software Requirements Engineering}

First, this activity was renamed «SY.2 Systems Requirements Engineering». A task SY.2.2 was added for eliciting and analysing requirements, as needs in input are not always available or may be available but incomplete and inconsistent (due to the variety of the stakeholders). A new document "Stakeholders' Requirements Document" was added. In task SY.2.3, the concept of system requirements and external functions were added, in response to the Stakeholders' Requirements. New documents "System Requirements Document" and "Justification Documents" were added. The concept of decomposing Systems into sub-systems according to the architecture to produce Sub Systems Requirements was added in SY.2.4. Finally, a new document "Sub Systems Requirements Document" was added. Table 5 describes System Requirements engineering tasks added of modified.

\begin{tabular}{|c|c|c|c|}
\hline Role & Task List & Input Products & Output Products \\
\hline $\begin{array}{l}\text { SENG } \\
\text { ACQ } \\
\text { STK }\end{array}$ & $\begin{array}{l}\text { SY.2.2 Elicit acquirer and other stakeholders } \\
\text { requirements and analyze system context } \\
\text { Identify and consult information sources of } \\
\text { requirements (Acquirer, users, stakeholders, previous } \\
\text { systems, documents, etc.). } \\
\text { Identify and analyze requirements to } \\
\text { - Determinate the scope and system boundary, } \\
\text { - Ensure that the necessary information / } \\
\text { requirements is available (completeness) and } \\
\text { consistent. Missing requirements should be } \\
\text { elicited. } \\
\text { Define scenarios, concepts of use of the system. } \\
\text { Analyze the context of use of the system with acquirer } \\
\text { and other stakeholders (environment, scenarios, } \\
\text { business processes...) } \\
\text { Generate or update the Stakeholders' Requirements }\end{array}$ & $\begin{array}{l}\text { Project Plan } \\
\text { - Needs and } \\
\text { expectations } \\
\text { - Previous System } \\
\text { Description }\end{array}$ & $\begin{array}{l}\text { Stakeholders' } \\
\text { Requirements Document } \\
\text { Justification Document } \\
\text { Traceability Record }\end{array}$ \\
\hline
\end{tabular}




\begin{tabular}{|c|c|c|c|}
\hline Role & Task List & Input Products & Output Products \\
\hline & $\begin{array}{l}\text { Document } \\
*_{\text {if necessary update the Justification Document to }} \\
\text { record the reasons of needs and establish traceability } \\
\text { with the requirements. }\end{array}$ & & \\
\hline $\begin{array}{l}\text { SENG } \\
\text { ACQ } \\
\text { STK }\end{array}$ & $\begin{array}{l}\text { SY.2.3 Elaborate System Requirements } \\
\text { Define the system boundary. } \\
\text { Define the external functions ensured by the system } \\
\text { (black box). } \\
\text { Define the applicable requirements and constraints to } \\
\text { the system } \\
\text { Define SMART system requirements and interfaces } \\
\text { Identify and resolve conflicts between acquirer, or } \\
\text { other stakeholders requirements (trade-offs). Update } \\
\text { the Justification Document and establish traceability } \\
\text { with the requirements. } \\
\text { Get the agreement on the system requirements with } \\
\text { ACQ and STK } \\
\text { Define or update traceability between system } \\
\text { requirements and stakeholder's requirements } \\
\text { according to the data model defined in SY1.3. } \\
\text { Generate or update the System Requirements } \\
\text { Document }\end{array}$ & $\begin{array}{l}\text { Stakeholders' } \\
\text { Requirements Document }\end{array}$ & $\begin{array}{l}\text { System Requirements } \\
\text { Document } \\
\text { Justification Document } \\
\text { Traceability Record }\end{array}$ \\
\hline $\begin{array}{l}\text { DES } \\
\text { SENG }\end{array}$ & $\begin{array}{l}\text { SY.2.4 Elaborate Sub Systems Design Requirements } \\
\text { In parallel of the functional and physical architectural } \\
\text { design, define or update the requirements that specify } \\
\text { the sub-systems/system elements. } \\
\text { Note: Sub-systems requirements become needs and } \\
\text { expectations in the input of the sub-system } \\
\text { implementation. } \\
\text { Define or update traceability between sub-system } \\
\text { requirements and system requirements according to } \\
\text { the data model defined in SY1.3. } \\
\text { Generate or update the System Requirements } \\
\text { Document } \\
\text { (*Optional, not applicable if the system is a low level } \\
\text { element that is not decomposed in the system } \\
\text { anymore) }\end{array}$ & $\begin{array}{l}\text { System Requirements } \\
\text { Document }\end{array}$ & $\begin{array}{l}\text { Sub Systems } \\
\text { Requirements Document } \\
\text { Traceability Record }\end{array}$ \\
\hline
\end{tabular}

Table 5 System Requirements engineering tasks added of modified (ISO 2012)

\section{Modifications to Activity SI.3 - Software Architecture and Detailed Design}

This activity was renamed « SY.3 System Functional and Physical Architectural Design ». Major changes were also made in this activity. In SY.3.3 the concept of Functional Architecture that includes internal functions and interfaces was added. The concept of trade-offs was introduced. In SY.3.4 the concept of Physical Architecture with allocation of functional artefacts and tradeoffs were added. The Test Cases and Test Procedures from software were replaced in SY.3.6 to SY.3.9 by IVVQ plans and Verification procedures. Table 6 describes System Functional and Physical Architectural Design tasks added of modified. 


\begin{tabular}{|c|c|c|c|}
\hline Role & Task List & Input Products & Output Products \\
\hline $\begin{array}{l}\text { SENG } \\
\text { DES }\end{array}$ & $\begin{array}{l}\text { SY.3.3 Document or update the Functional System } \\
\text { Design. } \\
\text { Elaborate the functional architecture with the internal } \\
\text { functions of the system and their relations, by } \\
\text { analyzing: } \\
\text { The System Requirements } \\
\text { The external functions of the system (black box) } \\
\text { Define the internal functions and interfaces. } \\
\text { Identify the artifacts to reuse. Decide whether to } \\
\text { make, buy or reuse. } \\
\text { Define in parallel the Sub-System requirements. } \\
\text { Make trade-offs among the different possible } \\
\text { functional architectures relative to the requirements. } \\
\text { Update the Justification Document and establish } \\
\text { traceability with the requirements. } \\
\text { Functional architecture can be done in a model based } \\
\text { environment and generated as a document. } \\
\text { Define or update traceability between system design } \\
\text { artifacts and systems requirements according to the } \\
\text { data model defined in SY1.3. }\end{array}$ & $\begin{array}{l}\text { System Requirements } \\
\text { Document [validated, } \\
\text { baselined] } \\
\text { Reuse constraints }\end{array}$ & $\begin{array}{l}\text { Functional System } \\
\text { Design } \\
\text { Justification Document } \\
\text { Traceability Record }\end{array}$ \\
\hline $\begin{array}{l}\text { SENG } \\
\text { DES }\end{array}$ & $\begin{array}{l}\text { SY.3.4 Document or update the Physical System } \\
\text { Design. } \\
\text { Elaborate the physical architecture by: } \\
\text { - analyzing the System Requirements (e.g. non } \\
\text { functional requirements) } \\
\text { - analyzing the Functional Architecture and } \\
\text { allocating internal functions to Sub-Systems or } \\
\text { Systems Elements } \\
\text { - Identifying Sub-systems or Systems Elements } \\
\text { to reuse. }\end{array}$ & $\begin{array}{l}\text { System Requirements } \\
\text { Document [validated, } \\
\text { baselined] } \\
\text { System Functional } \\
\text { Design }\end{array}$ & $\begin{array}{l}\text { Physical System Design } \\
\text { Justification Document } \\
\text { Traceability Record }\end{array}$ \\
\hline$\overline{D E S}$ & $\begin{array}{l}\text { SY.3.6 Establish or update IVVQ plans and } \\
\text { Verification Procedures for integration testing based } \\
\text { on System Requirements Specification and System } \\
\text { Design. }\end{array}$ & $\begin{array}{l}\text { System Requirements } \\
\text { Specification [validated, } \\
\text { baselined] } \\
\text { System Design [verified, } \\
\text { baselined] }\end{array}$ & $\begin{array}{l}\text { IVVQ plan and } \\
\text { Verification Procedures }\end{array}$ \\
\hline
\end{tabular}

Table 6. System Functional and Physical Architectural Design tasks added of modified (ISO 2012)

\section{Modifications to Activity SI.4 - Software Construction}

This activity was renamed "SY.4 Software Construction ». For this activity, the VSE is requested to refer to ISO/IEC TR 29110-5-1-2 management and engineering guide (ISO 2011e).

\section{Addition of Activity SY.5 - Physical Construction}

This activity, illustrated in Table 7, has been added to the software Basic profile. The Physical Construction activity develops the physical components of the system from the System Design. The activity provides: 
- Work Team review of the Project Plan to determine task assignment.

- Work Team review of the Physical Design.

- Physical Components to be developed and tested.

- Traceability between Physical Construction and Physical Architecture,

\begin{tabular}{|c|c|c|c|}
\hline Role & $\begin{array}{c}\text { Task List } \\
\end{array}$ & Input Products & Output Products \\
\hline $\begin{array}{l}\mathrm{TL} \\
\mathrm{DEV}\end{array}$ & $\begin{array}{l}\text { SY.5.1 Assign Tasks to the Work Team } \\
\text { members related to their role, according to the } \\
\text { current Project Plan. }\end{array}$ & $\begin{array}{l}\text { Project Plan } \\
\text { - Tasks }\end{array}$ & \\
\hline$\overline{\mathrm{DEV}}$ & SY.5.2 Understand Physical System Design. & $\begin{array}{l}\text { Physical Architecture } \\
\text { [verified, baselined] }\end{array}$ & \\
\hline$\overline{\mathrm{DEV}}$ & $\begin{array}{l}\text { SY.5.3 Construct or update System Elements } \\
\text { based on the Physical System Design. } \\
\text { Development units to prepare the fabrication. } \\
\text { Development units could be prototypes, pre- } \\
\text { series... } \\
\text { Fabrication of series } \\
\text { *In case of a component with software, } \\
\text { integrate the SW during physical components } \\
\text { fabrication. } \\
\left({ }^{*} \text { Optional) }\right.\end{array}$ & $\begin{array}{l}\text { Physical Architecture } \\
\text { [verified, baselined], } \\
\text { Traceability Record } \\
\text { [verified, baselined] }\end{array}$ & Components \\
\hline $\mathrm{DEV}$ & $\begin{array}{l}\text { SY.5.4 Design or update IVVQ plans and } \\
\text { Verification Procedures and apply them to } \\
\text { verify that the Components implements the } \\
\text { Physical Architecture } \\
\text { Verify the Components and their interfaces. } \\
\text { *Verify the integration of the software into } \\
\text { the System Elements. } \\
\left({ }^{*} \text { Optional) }\right.\end{array}$ & Components & Components [verified] \\
\hline $\mathrm{DEV}$ & $\begin{array}{l}\text { SY.5.5 Correct the defects found until } \\
\text { successful verification (reaching exit criteria) } \\
\text { is achieved. }\end{array}$ & Components [verified] & Components [corrected] \\
\hline $\mathrm{DEV}$ & $\begin{array}{l}\text { SY.5.6 Update the Traceability Record } \\
\text { incorporating Components data } \\
\text { (Requirements, CAD, IVVQ data) constructed } \\
\text { or modified. }\end{array}$ & \begin{tabular}{|l} 
Components data \\
[corrected] \\
\\
Traceability Record \\
[verified, baselined].
\end{tabular} & $\begin{array}{l}\text { Traceability Record } \\
\text { [updated] }\end{array}$ \\
\hline TL & $\begin{array}{l}\text { SY.5.7 Incorporate Components data and } \\
\text { Traceability Record to the System } \\
\text { Configuration as part of the baseline. }\end{array}$ & $\begin{array}{l}\begin{array}{l}\text { Components data } \\
\text { [corrected] }\end{array} \\
\text { Traceability Record } \\
\text { [updated] }\end{array}$ & $\begin{array}{l}\text { System Configuration } \\
\\
\text { - Components data } \\
\text { [corrected, baselined] } \\
\text { - } \\
\text { Traceability Record } \\
\text { [updated baselined] }\end{array}$ \\
\hline
\end{tabular}

Table 7. Physical construction activity and tasks added (ISO 2012)

\section{Modifications to Activity SI.5 - Software Integration and Tests}

This activity was renamed «SY.6 System Integration, Verification and Validation ». To this activity, Integration Verification, Validation and Qualification (IVVQ) plans and procedures 
were added to 4 tasks of the Software Basic Profile. Validation and Validation concepts were distinguished in SY.6.4 and SY.6.5 according to SE Handbook definitions. In SY.6.6 the process of problem analysis has been added since it was not defined in the software activity. Table 8 describes System Integration, Verification and Validation tasks added or modified.

\begin{tabular}{|l|l|l|l|}
\hline PR & $\begin{array}{l}\text { SY.6.4 Perform System verification using } \\
\text { IVVQ plan and IVVQ Procedures and } \\
\text { document results in Verification Report. } \\
\text { Prepare the acceptance of the system. }\end{array}$ & $\begin{array}{l}\text { System IVVQ plans and } \\
\text { Procedures }\end{array}$ & $\begin{array}{l}\text { System [tested] } \\
\text { Verification Report }\end{array}$ \\
\hline $\begin{array}{l}\text { PR } \\
\text { ACQ }\end{array}$ & $\begin{array}{l}\text { SY.6.5 Perform System validation using } \\
\text { IVVQ plan and IVVQ Procedures and } \\
\text { document results in Validation Report. } \\
\text { Prepare the acceptance of the system. }\end{array}$ & $\begin{array}{l}\text { System IVVQ plans and } \\
\text { Procedures }\end{array}$ & $\begin{array}{l}\text { System [tested] } \\
\text { Validation Report }\end{array}$ \\
\hline $\begin{array}{l}\text { SENG } \\
\text { DES } \\
\text { IVVQ }\end{array}$ & $\begin{array}{l}\text { SY.6.6 Identify and resolve the root causes } \\
\text { of identified problems } \\
\text { Analyze the origin of the problem: human } \\
\text { error, design problem, manufacturing } \\
\text { problem, wrong requirement, test problems, } \\
\text { logistic problems, operational/maintenance } \\
\text { problems. } \\
\text { Perform problem resolution and update } \\
\text { Problem Register }\end{array}$ & & Problem Register \\
\hline
\end{tabular}

Table 8. System Integration, Verification and Validation tasks added of modified (ISO 2012)

\section{Modifications to Activity SY.6 - Product Delivery}

This activity was renamed "SY.7 Product Delivery ». For this activity System training documentation was added in SY.7.4 to SY.7.6 to prepare transition to the operational use of the products. Table 9 describes the Product Delivery task modified.

\begin{tabular}{|l|l|l|l|}
\hline SENG & SY.7.4 Document the System training to & System Requirements & System Training Document \\
DES & prepare transition with System Requirements & Document [approved] \\
& Document and IVVQ plan. & IVVlans [approved] & \\
\hline
\end{tabular}

\section{Table 9. Product Delivery task modified (ISO 2012)}

Figure 6 shows the flow of information between the System Implementation Process activities including the most relevant work products and their relationship. 


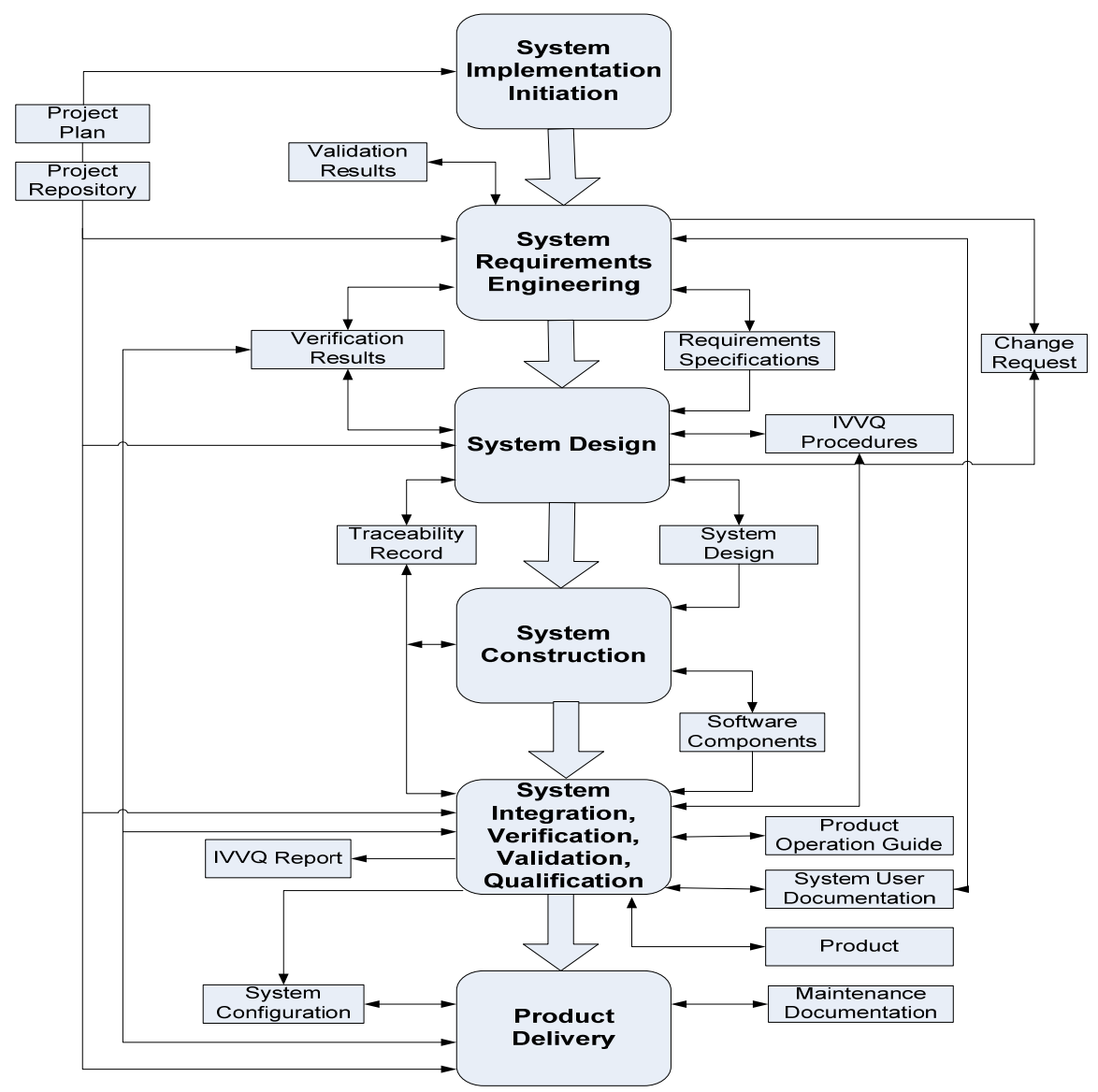

Figure 6. System Implementation process diagram of the proposed SE Basic Profile (ISO 2012)

\section{Roles for Systems Engineering and Management}

New roles were defined, the Analyst was replaced by a System Engineer. The Customer was replaced by the Acquirer and the Stakeholders. The Programmer was replaced by a Developer. A new role was also defined: the IVVQ Engineer. Table 10 is a list of the roles, its abbreviations and suggested competencies description.

\begin{tabular}{|l|l|c|l|}
\hline & \multicolumn{1}{|c|}{ Role } & Abbreviation & \multicolumn{1}{c|}{ Competency } \\
\hline 1. & Acquirer & ACQ & $\begin{array}{l}\text { Knowledge of the Customer processes and ability to explain the } \\
\text { Customer requirements. The customer is the role of the organization } \\
\text { that receives the product or service. In some context the customer is } \\
\text { the end user of the system. } \\
\text { The Acquirer (Customer representative) must have the authority to } \\
\text { approve the requirements and their changes. } \\
\text { The Customer representative includes user representatives in order to } \\
\text { ensure that the operational environment is addressed. } \\
\text { Knowledge and experience in the application domain. }\end{array}$ \\
\hline
\end{tabular}




\begin{tabular}{|l|l|c|l|}
\hline 2. & $\begin{array}{l}\text { Systems } \\
\text { Engineer }\end{array}$ & SENG & $\begin{array}{l}\text { Knowledge and experience eliciting, specifying and analyzing the } \\
\text { requirements. } \\
\text { Knowledge in designing user interfaces and ergonomic criteria. } \\
\text { Knowledge of the revision techniques. } \\
\text { Knowledge of the requirements authoring. } \\
\text { Knowledge of the business domain } \\
\text { Experience on the system development and maintenance. }\end{array}$ \\
\hline 3. & Developer & DEV & Knowledge in fabrication, development (HW, SW) \\
\hline 4. & IVVQ Engineer & IVVQ & $\begin{array}{l}\text { Knowledge in inspection techniques } \\
\text { Knowledge in testing }\end{array}$ \\
\hline 5. & Stakeholder & STK & $\begin{array}{l}\text { Stakeholders are participants that have an interest in the system, all } \\
\text { along its life cycle. } \\
\text { STK should have Knowledge of the Stakeholder (e.g. manufacturer, } \\
\text { maintainer, tester, logistic) processes and ability to explain the } \\
\text { Stakeholder requirements. } \\
\text { The Stakeholder (representative) must have the authority to approve } \\
\text { the requirements and their changes. } \\
\text { Knowledge and experience in the application domain. }\end{array}$ \\
\hline
\end{tabular}

Table 10. Additional Roles to the ISO 29110 software basic profile (ISO 2012)

\section{Product description}

Table 11 is a list of the new or modified SE input, output and internal process products, its descriptions, possible states and the source of the products. The source can be another process or an external entity to the project, such as the Acquirer. Product items in the table are based on ISO/IEC/IEEE 15289 (ISO 2011h) Information Items with some exceptions.

\begin{tabular}{|c|c|c|}
\hline Name & Description & Source \\
\hline $\begin{array}{l}\text { Justification } \\
\text { Document }\end{array}$ & 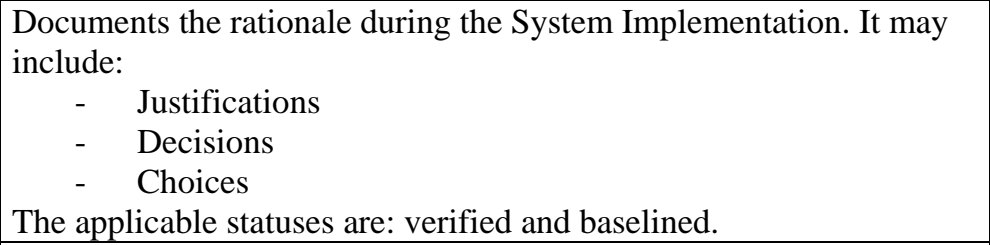 & \\
\hline $\begin{array}{l}\text { System Operation } \\
\text { Guide }\end{array}$ & 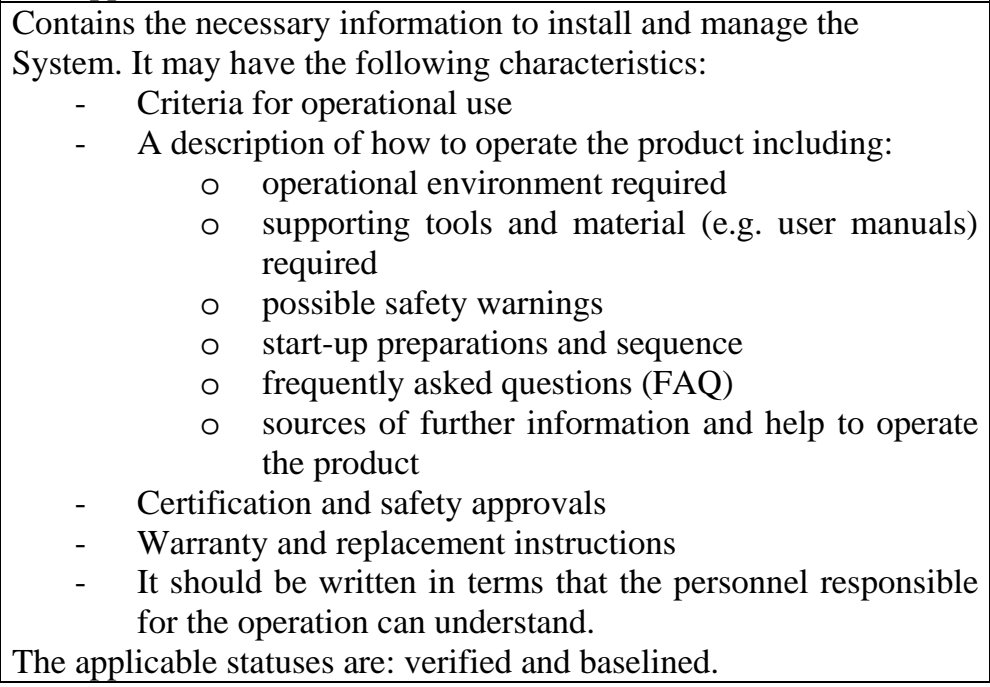 & $\begin{array}{l}\text { System } \\
\text { Implementation }\end{array}$ \\
\hline
\end{tabular}




\begin{tabular}{|c|c|c|}
\hline $\begin{array}{l}\text { System } \\
\text { Breakdown } \\
\text { Structure }\end{array}$ & $\begin{array}{l}\text { A hierarchical structure that represents the decomposition of the } \\
\text { system of interest into smaller systems and systems elements }\end{array}$ & Project Management \\
\hline $\begin{array}{l}\text { Stakeholders } \\
\text { Requirements } \\
\text { Specification }\end{array}$ & Identifies the stakeholder's requirements. & $\begin{array}{l}\text { System } \\
\text { Implementation }\end{array}$ \\
\hline $\begin{array}{l}\text { System } \\
\text { Requirements } \\
\text { Specification }\end{array}$ & $\begin{array}{l}\text { Identifies the system requirements that satisfy the stakeholders' } \\
\text { requirements. } \\
\text { Each requirement is identified, unique and it is verifiable or can be } \\
\text { assessed. } \\
\text { The applicable statuses are: verified, validated and baselined. }\end{array}$ & $\begin{array}{l}\text { System } \\
\text { Implementation }\end{array}$ \\
\hline System & $\begin{array}{l}\text { System item for an Acquirer, constituted by a collection of integrated } \\
\text { System Elements. The applicable statuses are: tested and baselined. }\end{array}$ & \begin{tabular}{|l|} 
System \\
Implementation
\end{tabular} \\
\hline System Elements & $\begin{array}{l}\text { A piece hardware, software, or hardware with software. } \\
\text { The applicable statuses are: verified, corrected and baselined. }\end{array}$ & $\begin{array}{l}\text { System } \\
\text { Implementation }\end{array}$ \\
\hline $\begin{array}{l}\text { System } \\
\text { Configuration }\end{array}$ & $\begin{array}{l}\text { A uniquely identified and consistent set of system products } \\
\text { The applicable statuses are: delivered and accepted. }\end{array}$ & $\begin{array}{l}\text { System } \\
\text { Implementation }\end{array}$ \\
\hline System Design & $\begin{array}{l}\text { Textual and/or graphical information on the System structure } \\
\text { (solution). This structure may include the following parts: } \\
\text { Functional Architecture: } \\
\text { - } \quad \text { Identifies the required Internal Functions } \\
\text { - } \quad \text { Identifies the relationship between Internal Functions } \\
\text { - } \quad \text { Consideration is given to any required: } \\
\text { - } \quad \text { System performance characteristics } \\
\text { - } \quad \text { Functional and human interfaces } \\
\text { - Security characteristics } \\
\text { Physical Architecture: } \\
\text { - Provides hardware design } \\
\text { - } \quad \text { Identifies the required Physical Elements } \\
\text { - Identifies the allocation of Internal Functions to Physical } \\
\text { - Elements } \\
\text { - Provides format of input / output interfaces: physical } \\
\text { - Defines the format of required data structures } \\
\text { The applicable statuses are: verified and baselined. }\end{array}$ & $\begin{array}{l}\text { System } \\
\text { Implementation }\end{array}$ \\
\hline IVVQ Procedures & $\begin{array}{l}\text { Elements needed to integrate, verify and validate the system. IVVQ } \\
\text { Procedures may include: } \\
\text { - } \quad \text { Identifies the IVVQ activities } \\
\text { - } \quad \text { Inspection, simulation, test items } \\
\text { - } \quad \text { Input specifications } \\
\text { - } \quad \text { Output specifications } \\
\text { - } \quad \text { Environmental needs } \\
\text { - } \quad \text { Special procedural requirements } \\
\text { - } \quad \text { Interface dependencies } \\
\text { Test Procedures may include: } \\
\text { - } \quad \text { Identifies: test name, test description and test completion } \\
\quad \text { date } \\
\text { - Identifies potential implementation issues } \\
\text { - } \quad \text { Identifies the person who completed the test procedure } \\
\text { - } \quad \text { Identifies prerequisites } \\
\quad \text { required procedion by the tester and the expected results } \\
\text { The applicable statuses are: verified and baselined. }\end{array}$ & $\begin{array}{l}\text { System } \\
\text { Implementation }\end{array}$ \\
\hline
\end{tabular}




\begin{tabular}{|c|c|c|}
\hline IVVQ Report & $\begin{array}{l}\text { Documents the tests execution. It may include: } \\
\text { - } \quad \text { A summary of each defect } \\
\text { - } \quad \text { Identifies the related test case } \\
\text { - } \quad \text { Identifies the tester who found each defect } \\
\text { - } \quad \text { Identifies the severity for each defect } \\
\text { - } \quad \text { Identifies the affected function(s) for each defect } \\
\text { - } \quad \text { Identifies the date when each defect originated } \\
\text { - } \quad \text { Identifies the date when each defect was resolved } \\
\text { - } \quad \text { Identifies the person who resolved each defect } \\
\text { The applicable status is: baselined. }\end{array}$ & $\begin{array}{l}\text { System } \\
\text { Implementation }\end{array}$ \\
\hline $\begin{array}{l}\text { Verification } \\
\text { Results }\end{array}$ & $\begin{aligned} & \text { Documents the verification execution. It may include the record of: } \\
& \text { - } \text { Participants } \\
& \text { - } \text { Date } \\
& \text { - } \text { Place } \\
& \text { - } \text { Duration } \\
& \text { - } \text { Verification check-list } \\
& \text { - } \text { Passed items of verification } \\
& \text { - } \text { Failed items of verification } \\
& \text { - } \text { Pending items of verification } \\
& \text { - } \text { Defects identified during verification } \\
&\end{aligned}$ & $\begin{array}{l}\text { Project Management } \\
\text { System } \\
\text { Implementation }\end{array}$ \\
\hline Validation Results & $\begin{aligned} & \text { Documents the validation execution, It may include the record of: } \\
& \text { - } \text { Participants } \\
& \text { - } \text { Date } \\
& \text { - } \text { Place } \\
& \text { - } \text { Duration } \\
& \text { - } \text { Validation check-list } \\
& \text { - } \text { Passed items of validation } \\
& \text { - } \text { Failed items of validation } \\
& \text { - } \text { Pending items of validation } \\
& \text { - } \text { Defects identified during validation } \\
&\end{aligned}$ & $\begin{array}{l}\text { System } \\
\text { Implementation }\end{array}$ \\
\hline
\end{tabular}

Table 11. Product Descriptions (ISO 2012)

\section{Deployment Packages}

The last step of the approach consisted of defining guidelines explaining in more detail the processes defined in the profiles. These guidelines will be freely accessible to VSEs on the internet as a collection of deployment packages. A deployment package (DP) is a set of artefacts developed to facilitate the implementation of a set of practices of the selected framework in a VSE (Laporte 2009). Since the INCOSE Handbook (INCOSE 2010) is a 'how to' document, it will be used to develop the set of DPs. The elements of a typical deployment package are: process description (e.g. activities, inputs, outputs, and roles), guide, template, checklist, example, presentation material, reference and mapping to standards and models, and a list of tools. Packages are designed such that a VSE can implement its content without having to implement the complete framework at the same time. The table of contents of a deployment package is illustrated in Table 12.

\begin{tabular}{|l|}
\hline 1. Introduction \\
\hline Purpose of this document \\
\hline Key Definitions \\
\hline 2. Why this Process is important \\
\hline 3. Overview of Main Tasks \\
\hline
\end{tabular}




\begin{tabular}{|l|}
\hline 3.1 Tasks \\
\hline 3.2 Roles and artefacts \\
\hline 3.3 Activity Lifecycle and examples of lifecycles \\
\hline Appendix A Templates \\
\hline Appendix B Checklists \\
\hline Appendix C Coverage Matrices (ISO 15288, ISO 9001, CMMI) \\
\hline Appendix D Tools \\
\hline Appendix E Training Material \\
\hline Appendix F Deployment Package Evaluation Form \\
\hline
\end{tabular}

Table 12. Table of contents of a SE deployment package (adapted from Laporte 2008)

Figure 7 illustrates the proposed set of SE Deployment Packages for the Basic Profile which will be available, at no cost, on the Internet.

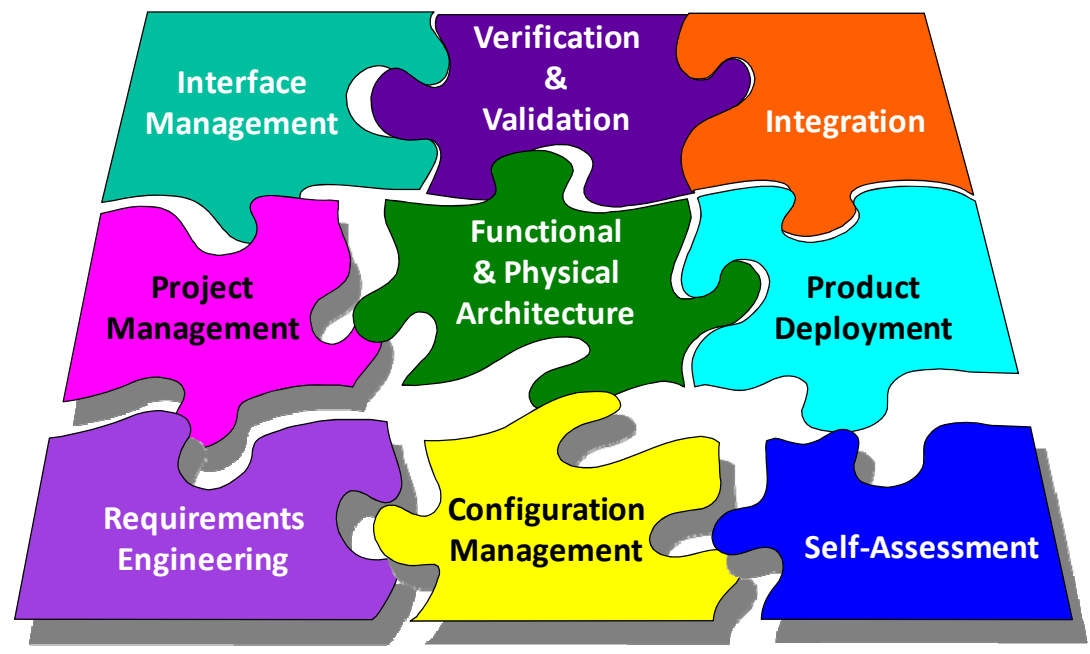

Figure 7. Proposed set of Deployment Packages for the SE Basic Profile (adapted from Fanmuy 2011)

Within AFIS, a draft Requirements Engineering Guide has been developed. The outline of the draft guide is illustrated in figure 8. It also describes good and counter productive requirements practices. 


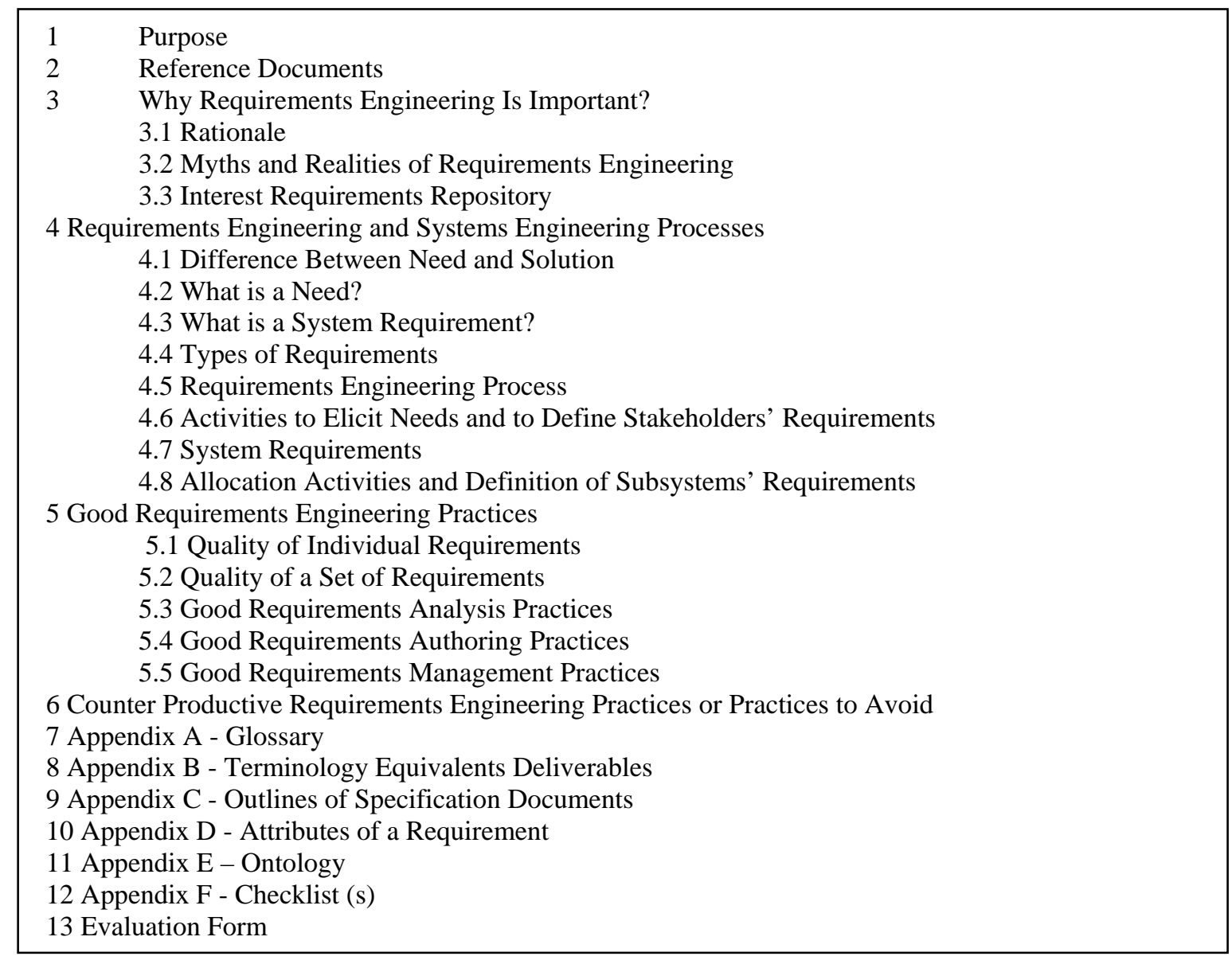

Figure 8. Outline of the proposed Requirements Engineering Guide (translated from Fanmuy 2011)

\section{Conclusion and Future Work}

Industry recognizes the contribution of VSEs in terms of the valuable products and services they offer. A large majority of organisations worldwide have up to 25 people. The current collection of ISO/IEC JTC1 SC7 standards is not easily applied in VSEs, which generally find standards difficult to understand. WG24, established by JTC1/SC7 to address this issue in 2005 developed a series of ISO/IEC 29110 standards and technical reports for VSEs involved in the development of software. The ISO/IEC 29110 SW Basic profile was used by members of INCOSE and AFIS to develop a draft version of a Basic Profile for VSEs involved in systems engineering. An official mandate was added to WG24, in September 2011, to develop a series of SE standards and guides.

With the development of a SE set of standards and guides, WG24 will review the existing ISO 29110 part 1 (Overview), part 2 (Framework and taxonomy), part 3 (Assessment guide) to broaden the scope from software engineering to systems engineering, therefore limiting the number of documents and the maintenance of these documents. It is expected that there will be separate Part 4 (Profile specifications) and Part 5 (Engineering and management guide) for 
software and systems engineering. Both software and systems engineering sets will have a common structure.

With regard to future work, WG24 plans to invite VSEs to participate in field trials. Since a few WG24 delegates are already working closely with VSEs, they will play a key role in coordinating the trials. These trials will help to validate the approach and obtain feedback in order to improve the documents before they go to ISO publication. Profiles and guides will also be circulated by ISO for review and ballot in 2012. WG24 is planning to produce a Final Draft of the SE Basic Profile Engineering and Management Guide in late 2012 or early 2013. Publication by the ISO/IEC is scheduled for 2013. Once published, a request will be sent to ISO to translate them into French and Spanish. Similar to the existing set of ISO/IEC 29110 SW technical reports, the new versions of Part 1, Part 3 as well as Part 5 should also be made available at no cost on this ISO site:

http://standards.iso.org/ittf/PubliclyAvailableStandards/index.html

Deployment packages, to support the future SE standard, are developed by members of INCOSE and will be made available to VSEs on public Web sites. The deployment packages will be heavily based on the INCOSE Handbook.

Once the ISO/IEC 29110 Entry profile for software is ready for publication, WG24 will start the development of an Entry profile for systems engineering. Similarly, once the ISO/IEC 29110 Intermediate and Advanced profiles are ready, WG24 should develop two matching systems engineering profiles for VSEs.

Since many VSEs developing systems are also involved in the development of critical systems, WG24 will conduct an analysis to determine if a set of systems/software engineering standards for VSEs developing critical systems should be developed.

Additional Information. The following Web site provides more information, as well as articles by WG24 members and deployment packages for software and systems engineering:

- http://profs.logti.etsmtl.ca/claporte/English/VSE/index.html

\section{References}

(Anacleto 2004) Anacleto, A., von Wangenheim, C. G.; Salviano, C. F.; Savi, R. Experiences gained from applying ISO/IEC 15504 to small software companies in Brazil, 4th International SPICE Conference on Process Assessment and Improvement, Lisbon, Portugal, April 2004, pp. 33-37.

(Charette 2005) Charette, R. N., Why Software Fails, IEEE Computer Society, Spectrum, September 2005, pp 4249.

(Fanmuy 2011) Fanmuy, G., L’Ingénierie et Management des Systèmes pour les PME/TPE et petits projets, Association Française d'Ingénierie Système (AFIS)/International Council on Systems Engineering (INCOSE), May 24th, 2011, Paris, France.

(Fanmuy 2012) Fanmuy, G., Collection AFIS, Guide " Pratique de l'ingénierie des exigences), Association Française d'Ingénierie Système (AFIS), decembre 2012, Paris, France. 
(INCOSE 2009) INCOSE VSME Project Charter, 2009. https://connect.incose.org/tb/vsme/default.aspx

(INCOSE 2010) Systems Engineering Handbook A Guide For System Life Cycle Processes And Activities, INCOSE-TP-2003-002-03.2, International Council on Systems Engineering (INCOSE), 7670 Opportunity Rd, Suite 220, San Diego, CA 92111-2222, January 2010

(ISO 1998) ISO/IEC TR 10000-1:1998, Information technology - Framework and taxonomy of International Standardized Profiles - Part 1: General principles and documentation framework. International Organization for Standardization/International Electrotechnical Commission: Geneva, Switzerland.

(ISO 2005) New Work Item Proposal - Software Life Cycles for Very Small Enterprises, ISO/IEC JTC1/SC7 N3288, May 2005. http://www.jtc1-sc7.org/.

(ISO 2008a) ISO/IEC/IEEE 12207:2008, Information technology - Software life cycle processes. International Organization for Standardization/International Electrotechnical Commission: Geneva, Switzerland.

(ISO 2008b) ISO/IEC/IEEE 15288:2008, Systems and software engineering - System life cycle processes, International Organization for Standardization/International Electrotechnical Commission: Geneva, Switzerland, 2008.

(ISO 2008c) ISO 9001:2008 Quality Management System Requirements, International Organization for Standardization, Geneva, Switzerland.

[ISO 10] ISO/IEC 24765:2010, Systems and Software Engineering Vocabulary, Organisation

internationale de normalisation, Genève, 2010, on line : www.computer.org/sevocab

(ISO 2011a) ISO/IEC TR 29110-1:2011, “Software Engineering - Lifecycle Profiles for Very Small Entities (VSEs) - Part 1: Overview”. Geneva: International Organization for Standardization (ISO), 2011. Available at no cost from ISO at: http://standards.iso.org/ittf/PubliclyAvailableStandards/c051150_ISO_IEC_TR 29110-1_2011.zip

(ISO 2011b) ISO/IEC 29110-2:2011 Software Engineering - Lifecycle Profiles for Very Small Entities (VSEs) - Part 2: Framework and Taxonomy, Geneva: International Organization for Standardization (ISO), 2011. Available from ISO at: http://www.iso.org/iso/iso_catalogue/catalogue_tc/catalogue_detail.htm?csnumber=51151

(ISO 2011c) ISO/IEC TR 29110-3:2011, “Software Engineering - Lifecycle Profiles for Very Small Entities (VSEs) - Part 3: Assessment Guide”. Geneva: International Organization for Standardization (ISO), 2011. Available at no cost at: http://standards.iso.org/ittf/PubliclyAvailableStandards/c051152_ISO_IEC_TR_29110-3_2011.zip

(ISO 2011d) ISO/IEC 29110-4-1:2011, “Software Engineering -- Lifecycle Profiles for Very Small Entities (VSEs) Part 4-1: Profile specifications: Generic profile group”. Geneva: International Organization for Standardization (ISO), 2011. Available from ISO at:

http://www.iso.org/iso/iso_catalogue/catalogue_tc/catalogue_detail.htm?csnumber=51154

(ISO 2011e) ISO/IEC TR 29110-5-1-2:2011- Software Engineering - Lifecycle Profiles for Very Small Entities (VSEs) - Part 5-1-2: Management and engineering guide - Generic profile group: Basic profile, International Organization for Standardization/International Electrotechnical Commission: Geneva, Switzerland. Available at no cost from ISO at: http://standards.iso.org/ittf/PubliclyAvailableStandards/c051153_ISO_IEC_TR_29110-51_2011.zip

(ISO 2011f) ISO/IEC JTC1/SC7 N5149, New Work Item Proposal - System Life Cycles for Very Small Entities, May 2011, International Organization for Standardization/International Electrotechnical Commission: Geneva, Switzerland.

(ISO 2011g) ISO/IEC JTC1/SC7 N5120, Resolutions SC7 Plenary Meeting, Paris 2011 (v1.0), June 11th 2011, International Organization for Standardization/International Electrotechnical Commission: Geneva, Switzerland. 
(ISO 2011h) ISO/IEC/IEEE 15289:2011, Systems and software engineering - Content of systems and software life cycle process information products (Documentation), International Organization for Standardization/International Electrotechnical Commission: Geneva, Switzerland.

(ISO 2012) ISO/IEC PDTR 30126-5:2012 - System Engineering - Lifecycle Profiles for Very Small Entities (VSEs) - Management and engineering guide: Generic profile group: Basic profile, International Organization for Standardization/International Electrotechnical Commission: Geneva, Switzerland. Note: The document number should be changed to ISO/IEC 29110.

(Laporte 2005) Laporte, C. Y., Renault, A., Desharnais, J. M., Habra, N., Abou El Fattah, M., Bamba, J. C, Initiating Software Process Improvement in Small Enterprises: Experiment with Micro-Evaluation Framework, SWDC-REK, International Conference on Software Development, University of Iceland, Reykjavik, Iceland, May 27-June 1, 2005, pp. 153-163.

(Laporte 2006) Laporte, C. Y., April, A., Applying Software Engineering Standards in Small Settings: Recent Historical Perspectives and Initial Achievements. In: Proceedings of the First International Research Workshop for Process Improvement in Small Settings. Software Engineering Institute, Carnegie Mellon University, CMU/SEI2006-Special Report-001, January 2006, pp. 39-51.

(Laporte 2008) Laporte, C. Y., Renault, A., Alexandre, S., Applying ISO/IEC Software Engineering Standards in Very Small Enterprises, in Software Process Improvement for Small and Medium Enterprises: Techniques and Case Studies, Idea Group Inc, Hershey, PA, 2008, pp 42-70.

(Laporte 2009) Contributions to software engineering and the development and deployment of international software engineering standards for very small entities (Doctoral dissertation, Université de Bretagne Occidentale, Brest.

(Laporte 2011a) The Development and Experimentation of an International Standard for Very Small Entities Involved in Software Development, International Council on Systems Engineering (INCOSE) Workshop, January 29th 2011, Phoenix (Arizona).

(Laporte 2011b) La nouvelle norme ISO/IEC 29110 pour les très petites organisations, Association Française d'Ingénierie Système (AFIS)/International Council on Systems Engineering (INCOSE), May 24th, 2011, Paris, France.

(NMX 2005) NMX-059-NYCE-2005, Information Technology-Software-Models of Processes and Assessment for Software Development and Maintenance. Part 01: Definition of Concepts and Products; Part 02: Process Requirements (MoProSoft); Part 03: Guidelines for Process Implementation; Part 04: Guidelines for Process Assessment (EvalProSoft), Ministry of Economy, Mexico, 2005.

(PMI 2008) A Guide to the Project Management Body of Knowledge (PMBOK® Guide), Forth edition, Project Management Institute, Newtown Square, PA, 2008.

(SEI 2010) Software Engineering Institute. (2010). CMMI for Development, Version 1.3, Pittsburgh PA: Carnegie Mellon University. CMU/SEI-2010-TR-033.

(Shintani 2006) Shintani, K, Empowered Engineers are Key Players in Process Improvement, Presentation at the First International Research Workshop for Process Improvement in Small Settings, Software Engineering Institute, CMU/SEI-2006-SR-01, Pittsburgh, PA, 2006.

\section{About the Authors}

Dr. Claude Y Laporte is a professor, since 2000, at the École de technologie supérieure (ÉTS), an engineering school, where he teaches software engineering. His research interests include software process improvement in small and very small organisations and software quality assurance. He has worked in defense and transportation enterprises for over 20 years. He 
received a Master's degree in Physics from the Université de Montréal, a Master's degree in Applied Sciences from the École Polytechnique de Montréal and a Ph.D. from the Université de Bretagne Occidentale (France). He is the Editor of ISO/IEC JTC1 SC7 Working Group 24 tasked to develop ISO/IEC 29110 life cycle standards and guides for very small entities. He is the Cochair of the INCOSE Systems Engineering for Very Small and Micro Entities WG. He is a member of INCOSE, IEEE, PMI and a member of the professional association of engineers of the Province of Québec (Ordre des ingénieurs du Québec). He is the co-author of 2 books on software quality assurance published in 2011 by Hermes Science-Lavoisier. Web site address: http://profs.etsmtl.ca/claporte/English/index.html

Gauthier Fanmuy is the Technical Director at ADN (http://www.adneurope.com), a Systems Engineering consulting company specialized in Requirements Engineering, Model Based Systems Engineering and Products Lines for complex and critical Systems. He has worked in the past years in the Automotive Industry at PSA Peugeot Citroen where he has deployed Requirements Engineering and DOORS in an engineering department. He previously worked in the Aeronautic Industry at Dassault Aviation where he managed several projects such as integration of electro-optics sensors on military aircrafts, development of complex system functions and re-engineering of MMI in object oriented approaches. He is also Deputy Technical Director of AFIS (French Association on Systems Engineering). He was previously chairman of Global Processes Technical Committee and also managed during 10 years of the AFIS Requirements Engineering Working Group. He is the chairman an international WG in INCOSE: Systems Engineering for Very Small and Small Entities and small project (VSMEs). As member of the IREB, he is playing a key role in the translation of the IREB certification material to French, and in the porting of the overall IREB certification scheme in French speaking regions. He is co-founder of the SPECIEF association for the promotion of Requirements Engineering in French (www.specief.org) and is porting within this association the overall IREB certification scheme in French speaking regions (http://certified-re.de/en/).

Ken Ptack is an INCOSE CSEP and a consultant for systems engineering. He has worked in the aerospace and defence industry for over 30 years. He has a Bachelors degree in Naval Engineering and a Masters degree in Systems Analysis. He is the Secretary of ISO/IEC JTC1 SC7 WG24, Co-chair of INCOSE Systems Engineering for Very Small and Micro Entities (VSMEs) WG, member of the INCOSE Requirements WG, the INCOSE Standards WG, and was the INCOSE President in 1999. 